\title{
Methyl chloride poisoning in four members of a family
}

\author{
LJUBICA SPEVAK, VALERIJA NADJ, and DRAŽEN FELLÉ \\ Clinic of Internal Diseases, Clinic of Neuropsychiatry, Medical Faculty, Novi Sad, Yugoslavia
}

Accidental methyl chloride poisoning caused by gas leakage from a refrigerator through a ruptured rubber connecting tube occurred in four members of a family. All the patients had symptoms of central nervous system and kidney damage, while in three of them jaundice was observed. The outcome of the intoxication was good in all cases.

Methyl chloride poisoning was first described by Gerbis in 1914 in two workers who were cleaning a methyl chloride container (Browning, 1965). Later cases were caused by gas leakage from refrigerators (Kegel, McNally, and Pope, 1929; Weinstein, 1937) some of which were fatal (Schwartz, 1926; Verrière and Vachez, 1949). One occurred in a man who was installing a refrigerator (Roche, Nicholas, and Marier, 1956) and others in industrial exposures (Hansen, Weaver, and Venable, 1953; Morgan, 1942).

\section{Case report}

Three sisters who worked in a butcher's shop were admitted to hospital for treatment of methyl chloride poisoning. The fourth member of the family, a brother, refused hospital treatment although he had the same symptoms. The intoxication had occurred two days earlier when gas and fluid from a refrigerator had been observed leaking on to the floor. They immediately began to collect the fluid and carried out the meat stored in the refrigerator. They spent about an hour in the same room until mechanics arrived to repair the damage. In the evening four hours later, all of them felt very weak and suffered from abdominal pains, vomiting, hiccups, and severe headache which they thought were due to the food they had eaten for supper. After that they lost consciousness until the next day. Neighbours told them that a doctor had visited them and given them some medication but it is not known what this was. After two days they were sent to hospital as the symptoms had not disappeared. The repair shop stated that the gas had been methyl chloride.

On admission to hospital the four patients gave the impression of being a group of drunkards: they were confused, somnolent and showed ataxia and dysarthria. Later, cerebellar symptoms of nystagmus and adiodochokinesis developed, and all of them showed disturbances involving cranial nerves (optic, oculomotor, and facial) as well as moderate extrapyramidal (tremor and muscle tone changes) and pyramidal (slightly elevated tendon reflexes) disturbances, while disturbances of sensation were practically absent. All patients had faint heart sounds, tachycardia of about $110 / \mathrm{min}$ and blood pressure of about $100 / 80 \mathrm{mmHg}$. The severest signs of intoxication were observed in one of the sisters who had had the longest exposure to methyl chloride. In addition to these symptoms she had jaundice and subconjunctival haemorrhages. The abdomen was tender in the epigastrium. No enlargement of liver or spleen was observed. The other two sisters had the same signs of poisoning, with yellowish colour of skin, and without subserous bleeding. The brother, whose exposure was the shortest, had quite normal skin colour. After symptomatic treatment with isotonic glucose, B complex vitamins, and oxygen all symptoms of intoxication disappeared except ataxia.

The following laboratory data were normal: number of red and white blood cells, platelets, and reticulocytes; red cell osmotic fragility test; coagulation factors; serum electrophoresis, cholesterol, alkaline phosphatase, SGPT, SGOT, fibrinogen; blood glucose, blood ammonia, bone marrow smears, blood pH, blood gases. Electroencephalograms were normal.

\section{Discussion}

Elevation of indirect bilirubin was observed in all three sisters. The appearance of jaundice in the course of methyl chloride poisoning has also been observed by others (Weinstein, 1937; Wood, 1951; Mackie, 1961). Mackie found centrilobular degenera- 
tive and necrotic changes in the liver on biopsy. Liver function tests in our patients were normal. Haemolysis can be excluded because of a normal haemogram, absence of reticulocytosis, and a normal osmotic fragility test as well as normal bone marrow cytology.

Kidney damage is clearly seen from the elevated serum creatinine and blood urea as well as proteinuria. In fatal cases, degenerative changes and changes similar to acute glomerulonephritis have been observed. In our cases symptoms of kidney damage disappeared after two weeks.

Abnormal laboratory findings and neurological disturbances are shown in Tables 1 and 2.

There is still danger of methyl chloride poisoning because of its presence in old refrigerators.

\section{References}

Browning, E. (1965). Toxicity and Metabolism of Industrial Solvents, pp. 230-241. Elsevier, Amsterdam.

Hansen, H., Weaver, N. K., and Venable, F. S. (1953). Methyl chloride intoxication: report of 15 cases. Archives of Industrial Hygiene and Occupational Medicine, 8, 328-334.

Kegal, A. H., McNally, W. D., and Pope, A. S. (1929). Methyl chloride poisoning from domestic refrigerators. Journal of the American Medical Association, 93, 353-358.

Mackie, I. J. (1961). Methyl chloride intoxication. Medical Journal of Australia, 11, 203-205.

Morgan, A. Jones (1942). Methyl chloride poisoning. Quarterly Journal of Medicine, 41, 29-43.

Roche, L. A., Nicholas, A., and Marier, J. (1956). Les lésions rénales au cour de l'intoxication par le chlorure

TABLE 1

Neurological and Psychic Disturbances

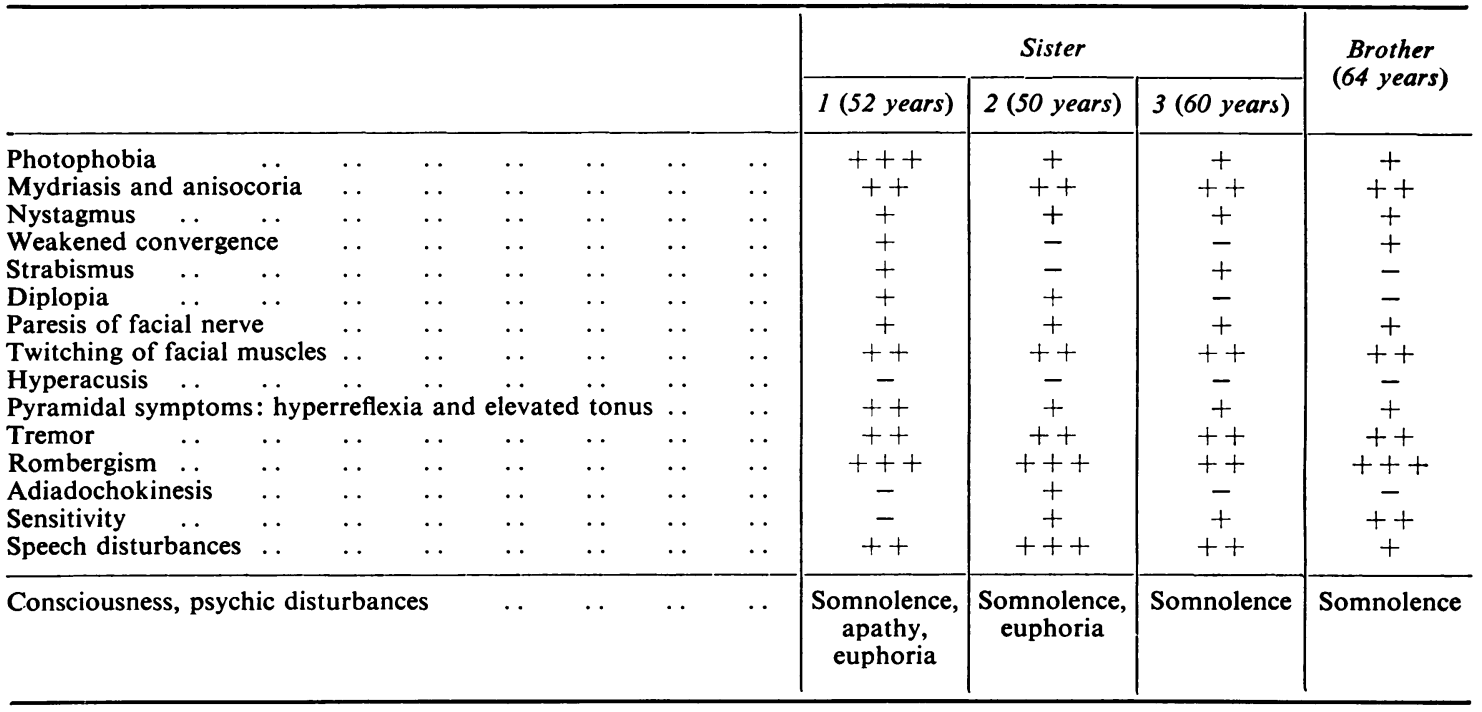

TABLE 2

Biochemical Analyses

\begin{tabular}{|c|c|c|c|c|c|c|}
\hline $\begin{array}{l}\text { Patient } \\
\text { and age } \\
\text { (years) }\end{array}$ & $\begin{array}{c}\text { Urine } \\
\text { protein }\end{array}$ & $\begin{array}{c}\text { Blood urea } \\
\text { in } \\
\text { mmol/l } \\
(\mathrm{mg} / 100 \mathrm{ml})\end{array}$ & $\begin{array}{c}\text { Bilirubin } \\
(\text { total }) \\
\mu m o l / l \\
(\mathrm{mg} / 100 \mathrm{ml})\end{array}$ & $\begin{array}{c}\text { Indirect } \\
\text { bilirubin } \\
\mu \mathrm{mol} / \mathrm{l} \\
(\mathrm{mg} / 100 \mathrm{ml})\end{array}$ & $\begin{array}{c}\text { Uric acid } \\
(\text { plasma }) \\
\text { mmol/l } \\
(\mathrm{mg} / 100 \mathrm{ml})\end{array}$ & $\begin{array}{c}\text { Creatinine } \\
\text { (plasma) } \\
\mu \mathrm{mol} / \mathrm{l} \\
(\mathrm{mg} / 100 \mathrm{ml})\end{array}$ \\
\hline $\begin{array}{l}\text { Sister } 1(52) \\
\text { Sister } 2(50) \\
\text { Sister } 3(60) \\
\text { Brother (64) }\end{array}$ & $\begin{array}{l}+ \\
+ \\
+ \\
+\end{array}$ & $\begin{array}{l}32 \cdot 2(194) \\
14 \cdot 1(85) \\
13 \cdot 8(83) \\
14 \cdot 1(85)\end{array}$ & $\begin{array}{l}34.0(1.99) \\
34.9(2.04) \\
18.1(1.06) \\
16.6(0.97)\end{array}$ & $\begin{array}{l}27.9(1.63) \\
30.8(1.80) \\
14.0(0.82) \\
12.3(0.72)\end{array}$ & $\begin{array}{l}0.52(8.8) \\
0.41(6.95) \\
0.37(6.25) \\
0.39(6.55)\end{array}$ & $\begin{array}{l}282.9(3 \cdot 2) \\
265 \cdot 2(3 \cdot 0) \\
150 \cdot 3(1 \cdot 7) \\
192 \cdot 7(2 \cdot 18)\end{array}$ \\
\hline
\end{tabular}


de methyl. Archives des Maladies Professionelles, 17, 430-433.

Schwartz, F. (1926). Vergiftungsfälle mit methylchloride. Deutsche Zeitschrift für die gesamte gerichtliche Medizin, 7, 278-282.

Verrière, P., and Vachez, M. (1949). Nephrite aiguë grave après intoxication par methylchloride. Lyon Médical, 1, 256-259.
Weinstein, A. (1937). Methyl chloride (refrigerator) gas poisoning. Journal of the American Medical Association, 108, 1603-1605.

Wood, M. W. (1951). Cirrhosis of the liver in a refrigeration engineer attributed to methyl chloride. Lancet, 1, 508-509.

Received for publication 23 June 1975

Accepted for publication 5 December 1975

\title{
Occupational health and safety in Great Britain 1974
}

\author{
M. A. COOKE
}

Albright \& Wilson Ltd, Oldbury, West Midlands, and

Department of Safety and Hygiene, University of Aston in Birmingham

Previous reviewers have commented upon the enormity of the task of producing these annual reports and of their possible co-ordination under the Health and Safety Commission. However, the present series emphasizes their value as documents in addition to the statistical data given in them. It is to be hoped that the reports will not be discontinued in their present format for this would be a loss to all who practise occupational medicine. The various accounts of activities in the occupational health sphere contrast with those of the Department of Health and Social Security, which of necessity report only briefly on matters of considerable interest and concern. HM Chief Inspector of Factories Annual Report (Department of Employment, 1975) is a document which is a model of its kind. With its sister volume, the report of the Employment Medical Advisory Service (Health and Safety Commission, 1975), it combines in a most readable way all the relevant statistical data, comments upon most aspects of the industrial health and safety field, and gives advice, admonition, and encouragement in a form that is entirely acceptable.
It is difficult to abstract this report as it is of such uniform standard, and so important that it should be read and kept for reference by all working in the health and safety field. This review, therefore, will be confined to comments upon several matters of particular importance or general interest. $\mathrm{Mr}$ Hammer, HM Chief Inspector of Factories refers to the Flixborough explosion and the part the Factory Inspectorate played in the subsequent investigation, and draws the conclusion that the Inspectorate may well be required 'to extend its role in prior assessment of major hazards'. This role may also extend in the field of new chemicals and in the detection of previously unrecognized hazards of chemicals already in use. There is the welcome comment that the Inspectorate's facilities for environmental testing are expanding. Together with the work undertaken in industry, it may well be possible for the United Kingdom to play an increasing and valuable part in the development of new techniques for atmospheric and biological testing for industrial hazards. The international work of the Inspectorate is already very considerable. It includes work in the EEC on plant, equipment, 